Ben-Gurion, R. \& Hertman, I. (1958). J. gen. Microbiol. 19, 289-297

\title{
Bacteriocin-like Material Produced by Pasteurella pestis
}

\author{
By RENANA BEN-GURION AND I. HERTMAN \\ Israel Institute for Biological Research, \\ Ness-Ziona, Israel
}

\begin{abstract}
SUMMARY: Strains of Pasteurella pestis under certain conditions form bacteriocinlike material, for which the name 'pesticin' is proposed; it inhibits the growth of $P$. pseudotuberculosis. The conditions necessary for induction of pesticin formation are similar to those which lead to induction of formation of some known bacteriocins. Of 24 strains of $P$. pestis tested, all but one produced pesticin. A mutant of $P$. pseudotuberculosis which was resistant to pesticin produced by one strain of $P$. pestis was found to be resistant to pesticin produced by all the other strains.
\end{abstract}

Reciprocal antibiotic actions were first described by Gratia (1925) and Fredericq (1946), who found that certain strains of Escherichia coli produce antibiotic substances that act specifically on other strains of the same species. These substances were named colicins (Fredericq, 1946). Further work showed that similar substances were also produced by many strains of Shigella (Fredericq, 1948a; Fastier, 1949), some strains of $E$. freundii (Fredericq, 1947), and a few Salmonella strains (Fredericq, 1952; Hamon, 1955). It was shown in 1952 (Jacob, Siminovitch \& Wollman, 1952), that it was possible to induce formation of colicin by irradiation of the bacteria under conditions similar to those which cause induction in lysogenic bacteria. The colicins differ in the extent and specificity of their activity and in their physical and chemical properties (Fredericq, 1948 $b$; Goebel, Barry \& Shedlovsky, 1956; Hamon, 1956; Ludford \& Lederer, 1953). Analogous substances were found in two other families of bacteria : pyocin, produced by Pseudomonas aeruginosa (Jacob, 1954), and megacin, produced by Bacillus megaterium (Ivanovics \& Alfoldi, 1955, 1957). The present paper describes the formation of bacteriocinlike material by strains of Pasteurella pestis; the substance will be referred to as 'pesticin'.

\section{METHODS}

Organisms. The following strains were used: A strain of Pasteurella pseudotuberculosis No. 134 C (kindly supplied by Professor H. B. Maitland, Department of Bacteriology, Manchester) and a streptomycin-resistant mutant of this strain. Strains of $P$. pestis: $8775,8776,8777,8779$, Bombay, TJW (NCTC), TRU Schuetz, Ts otten, P4, Pf2, TSR, P5, P3, P 2, P12, L37 (received from the Department of Bacteriology, Hebrew University, Jerusalem), EV 76, 243, H 2, Elis, 195, 1122 (kindly supplied by Professor G. Girard, Institut Pasteur, Paris). Kimberley strain $P$ (received from Institute Oswaldo Cruz, Rio de Janeiro), strain $\mathbf{P}$ in a rough stage ' $P R$ ', a streptomycin-resistant mutant of 
$P$. pestis strain TRU. A strain of Shigella dysenteriae (Shiga). A strain of Escherichia coli $\mathrm{K} 12(\lambda)$. A strain of Pasteurella tularensis strain Schu. Strains of Salmonella typhimurium, 156, 238, 243, 154, 246, 244.

Media. Tryptose broth (TS) consisted of Bacto Tryptose (Difco) $2 \%$ (w/v), $\mathbf{0 . 5} \% \mathrm{NaCl}(\mathrm{w} / \mathrm{v})$. Proteose peptone broth $\left(\mathrm{Pr}_{3}\right)$ consisted of Proteose peptone 3 (Difco) $2 \%(w / v), \mathrm{NaCl} \mathrm{0.5 \% (w/v),} \mathrm{glucose} 0.05 \%(w / v), \mathrm{Na}_{2} \mathrm{HPO}_{4}, \mathbf{0 . 5} \%$ $(w / v)$. Blood agar base (BAB) consisted of: blood agar base (Difco) $4 \%$ (w/v), defibrinated rabbit blood $3 \%(w / v)$. Tryptose agar (TSA) and proteose peptone agar $\left(\operatorname{Pr}_{3} A\right)$ were prepared as described for liquid media with the addition of agar (Difco) $2 \%(\mathrm{w} / \mathrm{v})$. Phosphate buffer contained $\mathrm{NaH}_{2} \mathrm{PO}_{4}$ $5 \%(w / v), \mathrm{Na}_{2} \mathrm{HPO}_{4} 5 \%(\mathrm{w} / \mathrm{v})(\mathrm{pH}=7)$. Trypsin solution:trypsin $1 / 300$ (Nutritional Biochemical Corporation, Cleveland, Ohio) was dissolved in a buffer salt solution of the following composition $(\%, \mathrm{w} / \mathrm{v}): \mathrm{NaCl}, 0 \cdot 8 ; \mathrm{KCl}, \mathbf{0 . 0 2}$; $\mathrm{Na}_{2} \mathrm{HPO}_{4}, 0 \cdot 115 ; \mathrm{KH}_{2} \mathrm{PO}_{4}, 0.02 ; \mathrm{MgCl}_{2} 6 \mathrm{H}_{2} \mathrm{O}, 0.01 ; \mathrm{CaCl}_{2}, 0 \cdot 01$.

Conditions of cultivation. Stock cultures were maintained on BAB slopes. Broth cultures were started from $24 \mathrm{hr}$. blood agar slopes and incubated at $28^{\circ}-30^{\circ}$ for $20-24 \mathrm{hr}$. on a shaker.

Ultra-violet irradiation. The irradiation of $4 \mathrm{ml}$. samples in $9 \mathrm{~cm}$. Petri dishes (less than $2 \mathrm{~mm}$. layer of liquid) was carried out under constant agitation. A G15T 8 hot Sterilamp (Westinghouse Electric Corporation, Bloomfield, N.J., U.S.A.) was used for irradiation. The intensity (measured with a SM-600 u.v. indicating meter for sterilamps) was 300 ergs $\mathrm{sec}^{-1} \mathrm{~cm}^{-2}$ at a distance of $87 \mathrm{~cm}$. The same dose was used for irradiation of bacteria on solid media. After irradiation all further work was performed in dim light to avoid photo-reactivation.

Exposure to sonic vibration. Five to $10 \mathrm{ml}$. samples were exposed to sonic vibrations at $10 \mathrm{kc}$. in a $250 \mathrm{~W}$. 'Raytheon' magnetostriction oscillator, Model DF 101 (Raytheon Manufacturing Co., Waltham, Mass., U.S.A.).

Optical density. The optical density of suspensions of organisms was measured with a Coleman Junior spectrophotometer at a wave length of $590 \mathrm{~m} \mu$.

Viable count. Samples $(0.1 \mathrm{ml}$.) of an appropriate dilution of a culture were plated on $\mathrm{BAB}$ medium. The colonies were counted after incubation for $48 \mathrm{hr}$. at $30^{\circ}$.

Demonstration of pesticinogenic properties (two-layer method, Fredericq, $1954 a$ ). The bacteria tested for pesticin production were seeded in $1 \mathrm{ml}$. of $\operatorname{Pr}_{3} \mathbf{A}$ on a basal medium $\left(\operatorname{Pr}_{3} A\right)$ layer. Immediately after the $1 \mathrm{ml}$. of agar solidified, a second layer of $10 \mathrm{ml}$. of $\operatorname{Pr}_{3} \mathrm{~A}$ was poured over the first and the plate incubated for 3 days at $30^{\circ}$. At the end of this period, when isolated colonies of the seeded culture appeared between the two layers of agar, the sterile surface of the upper layer was seeded evenly with the indicator strain, Pasteurella pseudotuberculosis. This was done by means of filter-paper which was soaked in a suspension of that strain. After $24 \mathrm{hr}$. further incubation at $37^{\circ}$, the indicator strain developed uniformly, except for some circular inhibition zones situated above the active colonies.

Pesticin titration. The pesticin was titrated by spotting drops $(0.01 \mathrm{ml}$.) of a series of dilutions of the preparation to be titrated, on the surface of a plate 
seeded with the indicator strain. The indicator plates were prepared some minutes before the titration by soaking a filter-paper in a suspension of the strain and leaving the paper on the plates for $5 \mathrm{~min}$. The plates were then incubated at $37^{\circ}$ for $24 \mathrm{hr}$. In this way a series of zones of decreasing inhibition was obtained ranging from complete inhibition through partial inhibition to normal growth. The highest dilution that gave a visible inhibition zone was defined as containing one arbitrary unit $/ \mathrm{ml}$.

\section{RESULTS}

Pesticin formation

The supernatant fluid from a well-aerated $48 \mathrm{hr}$. broth culture of Pasteurella pestis, grown at $30^{\circ}$, contained a substance (pesticin) which inhibited the growth of $\boldsymbol{P}$. pseudotuberculosis.

After centrifugation of culture in the cold at $3000 \mathrm{rev} . / \mathrm{min}$. for $20 \mathrm{~min}$. its supernatant fluid was treated as follows: (a) by addition of a few drops of chloroform to the supernatant, vigorous shaking for $10 \mathrm{sec}$,, decantation followed by aeration of the liquid for $20 \mathrm{~min}$. at $37^{\circ}$ (to remove the residual chloroform); (b) by addition of $500 \mu \mathrm{g}$. dihydrostreptomycin (sulphate)/ml. and using as indicator a streptomycin-resistant mutant. Checks for sterility were performed after each treatment. These treatments did not destroy pesticin activity. Filtration of the supernatant fluid through ultra-fine sintered glass filters sometimes decreased the inhibitory effect.

When material from the agar surface of an inhibitory zone was transferred (bacteriological loop) to another plate with an indicator strain, no inhibition was seen. The inhibiting agent could not be transferred in series.

Transmission of pesticinogenic properties. By means of the two-layer method it was found that each bacterium in a population of a pesticinproducing strain was capable of transmitting this property to its descendants (Pl. 1).

Influence of media on activity. Experiments showed that the media on which pesticin was titrated considerably influenced the results. While one batch of TSA gave very good results, a different batch did not show any inhibition of Pasteurella pseudotuberculosis growth. No differences were found between different batches of $\operatorname{Pr}_{3} A$. The media on which pesticin was titrated were always adjusted to $\mathrm{pH} 7$.

In liquid media inhibition of Pasteurella pseudotuberculosis growth by pesticin was observed but no quantitative results could be obtained. All pesticin titrations described in this paper were performed on solid media (see 'Methods').

Temperature influence on pesticin activity. The activity of pesticin was 20 times higher when tested at $37^{\circ}$ than at $30^{\circ}$. Table 1 shows the respective activities obtained in the titration of pesticin on plates incubated for $24 \mathrm{hr}$. at $37^{\circ}$ and $30^{\circ}$.

It should be noted that Pasteurella pseudotuberculosis grows more abundantly at $37^{\circ}$ than at $30^{\circ}$ (unlike $P$. pestis). 
As the pesticin was added directly on the indicator bacteria (Pasteurella pseudotuberculosis) and the presence and not the diameter of the inhibition zone was considered, no allowance was made for the variation in diffusion rate in agar resulting from differences in temperature.

Table 1. Temperature influence on pesticin activity (activity

\begin{tabular}{|c|c|c|}
\hline \multicolumn{3}{|c|}{ expressed in arbitrary units) } \\
\hline $\begin{array}{c}\text { Samples of } \\
\text { pesticin }\end{array}$ & $\begin{array}{l}\text { Activity } \\
\text { measured } \\
\text { at } 37^{\circ}\end{array}$ & $\begin{array}{c}\text { Activity } \\
\text { measured } \\
\text { at } 30^{\circ}\end{array}$ \\
\hline 1 & 400 & 20 \\
\hline 2 & 1,000 & 50 \\
\hline $\mathbf{3}$ & 2,000 & 75 \\
\hline 4 & 10,000 & 200 \\
\hline $\mathbf{5}$ & 8,000 & 300 \\
\hline
\end{tabular}

Production of pesticin by different strains and spectrum of activity. Out of 24. strains of Pasteurella pestis tested, only strain TRU failed to produce pesticin. This strain was not sensitive to the pesticin produced by other strains of $\boldsymbol{P}$. pestis. Attempts to transduce the pesticinogenic properties of other strains of $P$. pestis to strain TRU, by growing the two strains together, were not successful (cf. Fredericq, 1954b). P. tularensis strain Schu., Escherichia coli K12 ( $\lambda$ ), Shigella dysenteriae (Shiga), and 6 strains of Salmonella typhimurium, were not sensitive to pesticin. A P. pseudotuberculosis mutant, resistant to the pesticin produced by one strain of Pasteurella, was resistant to the pesticin produced by all other strains.

\section{Chemical and physical properties of pesticin}

Nature of pesticin. Pesticin is sensitive to proteolytic enzymes. Its activity is completely destroyed by incubation with $0.025 \%(w / v)$ trypsin for 20 min. (1/300 NBC) at $37^{\circ}(\mathrm{pH} 7)$. It has a relatively high molecular weight since it diffuses slowly in agar and does not pass through cellophan.

Table 2. Effect of heat on pesticin activity (pesticin activity expressed in arbitrary units)

$\begin{array}{ccc}\begin{array}{c}\text { Original value } 2000 \\ \text { Time of heating }\end{array} & \text { In boiling water } & \text { At } 60^{\circ} \\ 1 \mathrm{~min} . & 100 & - \\ 3 \mathrm{~min} . & 50 & - \\ 5 \mathrm{~min} . & 50 & - \\ 15 \mathrm{~min} . & 2 & - \\ 1 \mathrm{hr} . & - & 50 \\ 2 \mathrm{hr} . & - & 25 \\ 3 \mathrm{hr} . & - & 2\end{array}$

Heat. Pesticin is thermolabile, its activity is decreased by more than $95 \%$ through heating for $5 \mathrm{~min}$. in boiling water. A similar effect is obtained by heating to $60^{\circ}$ for $3 \mathrm{hr}$. Table 2 gives an example of the effect of heat on pesticin. Most of its activity is lost after one day at room temperature $\left(30^{\circ}\right)$ 
and it cannot be kept for more than a few days in an ordinary refrigerator. Storage for 3 months at $-20^{\circ}$ did not decrease its activity.

$p H$. Pesticin is stable between $\mathrm{pH} 6$ and 8 ; outside this range its activity diminishes. Table 3 shows the effect of variation in the $\mathrm{pH}$ of the media $\left(\mathrm{Pr}_{3}\right)$, containing the pesticin, on its activity. The media containing pesticin were kept for $2 \mathrm{hr}$. at $37^{\circ}$ at various $\mathrm{pH}$ values. Part of the medium was brought back to its original $\mathrm{pH}(7)$, while the remainder was kept at the altered $\mathrm{pH}$ value. Titration was then carried out in the usual manner on both parts. Where the titration of pesticin was carried out at a $\mathrm{pH}$ different from 7 , the dilution solution $\left(\mathrm{Pr}_{3}\right)$ was adjusted to the identical $\mathrm{pH}$ value. Where the $\mathrm{pH}$ which was outside 6-8 range was brought back to 7 , the activity did not return to its previous value.

Table 3. Activities of pesticin at different $\mathrm{pH}$ values (activity measured in arbitrary units of pesticin)

$\begin{array}{crc}\text { pH } & \begin{array}{c}\text { Titration without } \\ \text { further alteration } \\ \text { in pH }\end{array} & \begin{array}{c}\text { Titration after } \\ \text { readjustment } \\ \text { to pH 7 }\end{array} \\ 12 & 2 & 2 \\ 11 & 100 & 100 \\ 10 & 800 & 800 \\ 9 & 1000 & 1000 \\ 7 & 2000 & 2000 \\ 5 & 1000 & 1000 \\ 4 & 400 & 400 \\ 3 & 100 & 100 \\ 1.5 & 50 & 50\end{array}$

U.v. irradiation. Pesticin is very resistant to u.v. irradiation. No decrease in activity was detected after irradiation for $75 \mathrm{~min}$. at $300 \mathrm{erg}$. $\mathrm{sec} .^{-1} \mathrm{~cm} \cdot .^{-2}$.

Adsorption. Pesticin is completely adsorbed by Seitz filters and partly by sintered glass filters.

\section{Induction of pesticin biosynthesis}

The formation of pesticin by strains of Pasteurella pestis could be induced by u.v. irradiation. The conditions of pesticin induction were found to be similar to the conditions for induction of other bacteriocins in bacteriocinogenic bacteria (Kellenberger \& Kellenberger, 1956; Hamon \& Lewe, 1955).

Liquid cultures (24 hr.) of Pasteurella pestis in media TS or $\mathrm{Pr}_{3}$, of optical density $\geqslant 90$, did not contain pesticin. When these cultures were exposed to sonic vibrations for $20 \mathrm{~min} ., 88 \%$ of the bacteria were disintegrated, but no pesticin was found in the culture fluid. A similar medium containing pesticin, subjected to the same degree of sonic vibration for 20 min., did not show any decrease in the activity of pesticin.

When 24 hr. cultures of Pasteurella pestis were irradiated with a suitable dose of u.v. radiation pesticin appeared in the medium. An example of pesticin formation after u.v. irradiation is shown in Fig. 1. In this and similar 
experiments it was observed that after irradiation, pesticin appeared in the medium after $15 \mathrm{~min}$. at $37^{\circ}$, and only after $30 \mathrm{~min}$. at $30^{\circ}$. (The optimum temperature for growth of $P$. pestis is $30^{\circ}$.)

The amount of pesticin liberated into the medium increased with time; at $37^{\circ}$ it reached the maximum $2 \mathrm{hr}$., and at $30^{\circ}$ in $3 \mathrm{hr}$. after irradiation. The irradiation itself caused a decrease in viable bacterial count of $50 \%$ (irradiation for $90 \mathrm{sec}$.). No decline in bacterial count during incubation of the irradiated culture was detected.

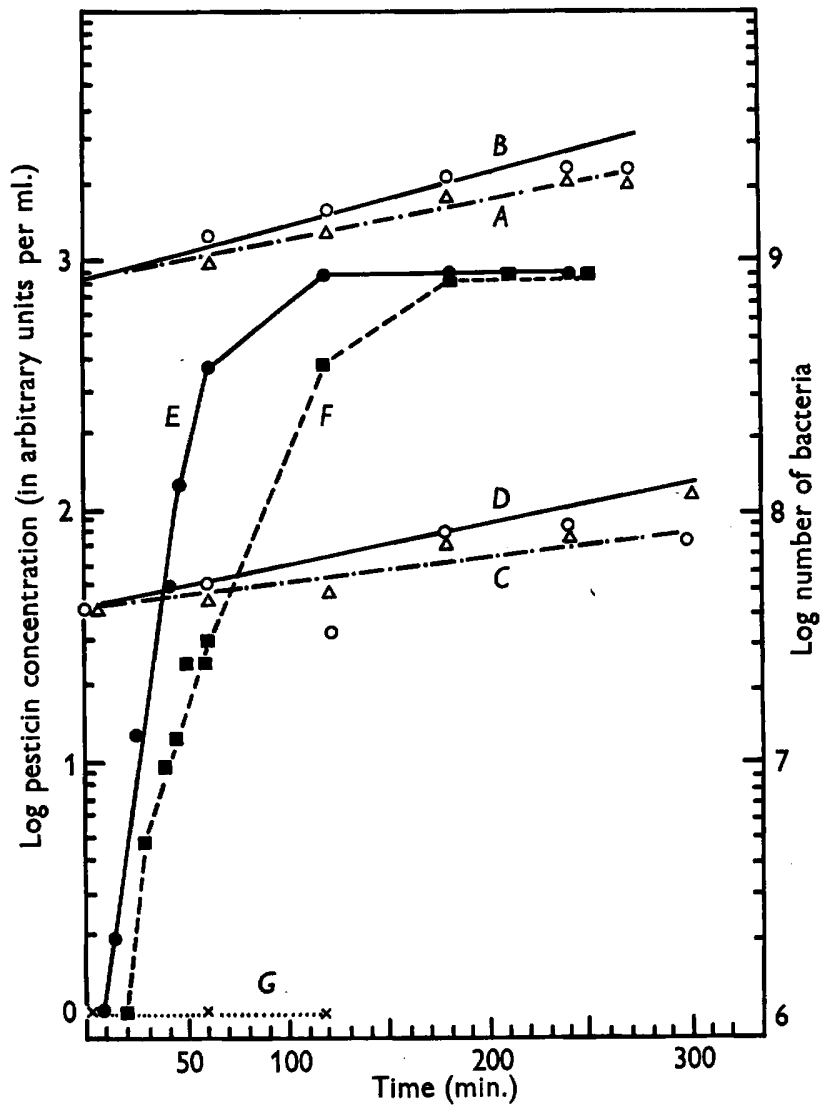

Fig. 1. Pesticin formation after u.v. irradiation of a culture of Pasteurella pestis, 'strain Kimberley (P), grown and irradiated in $\mathrm{Pr}_{3}$ medium. The times of irradiation were zero and 90 sec. optical density 98 . Pesticin concentration expressed in arbitrary units per ml. $A$, Count of non-irradiated bacteria at $37^{\circ} ; B$, count of non-irradiated bacteria at $30^{\circ} ; C$, count of irradiated bacteria at $37^{\circ} ; D$, count of irradiated bacteria at $30^{\circ}$; $E$, pesticin formation at $37^{\circ} ; F$, pesticin formation at $30^{\circ} ; G$, pesticin formation at $0^{\circ}$.

\section{Irradiation of organisms on solid media}

Microcolonies of Pasteurella pestis on medium $\operatorname{Pr}_{3} \mathrm{~A}$ formed after incubation for $20 \mathrm{hr}$. were irradiated for $90 \mathrm{sec}$. and then tested for pesticin formation by the double-layer method. Inhibition zones appeared without visible bacterial growth of $\boldsymbol{P}$. pestis (Pl. 1, fig. 2). No inhibition zones were formed when the 
bacteria on agar were killed by exposure to chloroform vapour immediately after irradiation. Exposure of the bacteria to chloroform vapour $2 \mathrm{hr}$. after irradiation did not affect the formation of the inhibition zones.

\section{Pesticin formation in buffer}

Pasteurella pestis, grown for $24 \mathrm{hr}$. in medium $\mathrm{Pr}_{3}$, was washed twice with phosphate buffer and then irradiated $(90 \mathrm{sec}$.). Immediately after irradiation one part of the bacterial suspension was diluted $1 / 4$ in $\operatorname{Pr}_{3}$ medium, and another part was similarly diluted in phosphate buffer and both suspensions were incubated at $37^{\circ}$. After $2 \mathrm{hr}$. of incubation, pesticin was formed only in the $\operatorname{Pr}_{3}$ broth; there was no formation of pesticin in phosphate buffer.

Inducibility of different strains of Pasteurella pestis. U.v. irradiation induced the production of pesticin by all the strains which could produce it spontaneously. Strain TRU which did not form pesticin spontaneously, did not produce it after u.v. irradiation.

\section{DISCUSSION}

The production of antibiotic material which inhibits the growth of Pasteurella pseudotuberculosis seems to be a common phenomenon in the species $P$. pestis; 23 out of 24 strains tested (or 22 out of 23 strains, if strain EV and ELIS are identical; Girard, 1957) produced pesticin.

The properties of pesticin allow it to be distinguished from classical antibiotics and to be classified with other bacteriocins, i.e. protein-like substances produced by bacteria which inhibit specifically related strains. The formation of some bacteriocins can be induced by ultraviolet irradiation. While generally as a result of induced formation of other bacteriocins bacteria are lysed (Jacob et al. 1952; Ivanovics \& Alfoldi, 1957; Jacob, 1954), pesticin formation after u.v. irradiation is not accompanied by total lysis. It is possible that only a very small proportion of the population produces pesticin and undergoes lysis. The methods used here (viable count and spectrophotometry) are not sensitive enough to detect a change in less than $10 \%$ of the population. It is therefore possible that production of pesticin is accompanied by lysis of a small proportion of the population. According to some authors (Fredericq, 1954 c; Hamon \& Lewe, 1955; Kellenberger \& Kellenberger, 1956), however, induction of colicin formation does not result in lysis, unless the strains are also lysogenic. Kellenberger \& Kellenberger (1956) examined 63 colicinogenic strains of Escherichia coli and concluded that strains that were only colicinogenic did not undergo lysis after u.v. irradiation, while a complete or partial lysis was always due to the presence of developing bacteriophage in the bacteria. After irradiation of colicinogenic, but not lysogenic bacteria, a residual growth of the bacteria was observed, and this was followed by an apparently stationary phase in the growth, while the production of colicin continued (Hamon \& Lewe, 1955). In the case of pesticin formation following irradiation, no stationary phase in the growth curve was observed. The bacterial count increased during pesticin formation. It is quite possible that the expected plateau was masked by the growth of non-induced bacteria. 
When bacteria on agar plates are induced by u.v. irradiation to form pesticin, they do not form colonies. This may indicate that pesticin synthesis is a lethal biosynthesis, and that the growth of organisms in irradiated liquid medium might be due to the growth of organisms which were not affected by irradiation.

We are indebted to Miss K. Schajevitz for excellent technical assistance.

\section{REFERENCES}

FASTIER, L. B. (1949). An antibiotic substance produced by a member of the Shigella group. J. Immunol. 62, 399.

FredericQ, P. (1946). Sur la spécificitée des actions antibiotiques. Schroeiz. Z. allg. Path. 9, 385.

FredericQ, P. (1947). Recherche comparé des propriétées biochimiques et des propriétées antibiotiques dans le groupe Coli-Aerogenes. Bull. Soc. Chim. biol., Paris, 29, 359.

FredericQ, P.(1948 a). Production des substances antibiotiques par certaines souches de Shigella. C.R. Soc. Biol., Paris, 142, 399.

Fredericq, P. (1948b). Antibiotiques réciproques chez les Enterobacteriaceae. Rev. belge Path. (Suppl. 4), 19, 1.

FredericQ, P. (1952). Recherche des propriétées lysogènes et antibiotiques chez les Salmonella. C.R. Soc. Biol., Paris, 146, 298.

FredericQ, P. (1954a). Transduction génétiques des propriétées colcinogènes chez Escherichia coli et Shigella sonnei. C.R. Soc. Biol., Paris, 148, 399.

FredericQ, P. (1954 $b$ ). Role éventuel des propriétées lysogènes dans la transduction des propriétées colcinogènes chez Escherichia coli. C.R.Soc. Biol., Paris, 148, 624.

Frederica, P. $(1954 c)$. Induction de la production de colicine par irradiation ultraviolette des souches colicinogènes d'Escherichia coli. C.R. Soc. Biol., Paris, 148, 1276.

Grard, G. (1957). Considération sur une souche de Pasteurella pestis isolée à partir d'un cheval au Congo Belge. Son étroit apparentement à la souche EV (Girard et Robic). Bull. Soc. Pat. exot. 50, 346.

Goeber, W. F., Barry, G. G. T. \& Shedlovsky, T. (1956). The production of colicin $\mathrm{K}$ in media maintained at constant pH. J. exp. Med. 103, 577.

Gratia, A. (1925). Sur un remarquable exemple d'antagonism entre deux souches de Colibacille. C.R. Soc. Biol., Paris, 93, 1040.

Hamon, Y. (1955). Étude d'une colicine élaborée par une culture de $S$. paratyphi B. Ann. Inst. Pasteur, 88, 193.

Hamon, Y. (1956). Les bacteriocines sont-elles des substances antigéniques? C.R. Acad. Sci., Paris, 242, 1240.

Hamon, Y. \& LEwE, Z. V. (1955). Étude de l'induction par l'irradiation ultraviolette de quelques cultures d' $E$. coli $\mathrm{K} 12$ préalablement rendues colicinogènes par transduction. Ann. Inst. Pasteur, 89, 336.

Ivanovics, G. \& AlföLdr, L. (1955). Observation on lysogenesis in Bacillus megaterium and on megacine, the antibacterial principle of this bacillus species. Acta microbiol. Acad. Sci., Hung. 2, 275.

Ivanovics, G. \& ALFöLdr, L. (1957). Bacteriocinogenesis in Bacillus megaterium. J. gen. Microbiol. 16, 522.

$\mathrm{J}_{\mathrm{ACOB}}, \mathrm{F}$. (1954). Biosynthèse induite et mode d'action d'une pyocine, antibiotique de Pseudomonas pyocianea. Ann. inst. Pasteur, 86, 149.

Jacob, F., Siminovitch, L. \& Wollman, E. (1952). Sur la biosynthèse d'une colicine et sur son mode d'action. Ann. Inst. Pasteur, 83, 295. 

Journal of General Microbiology, Vol. 19, No. 2

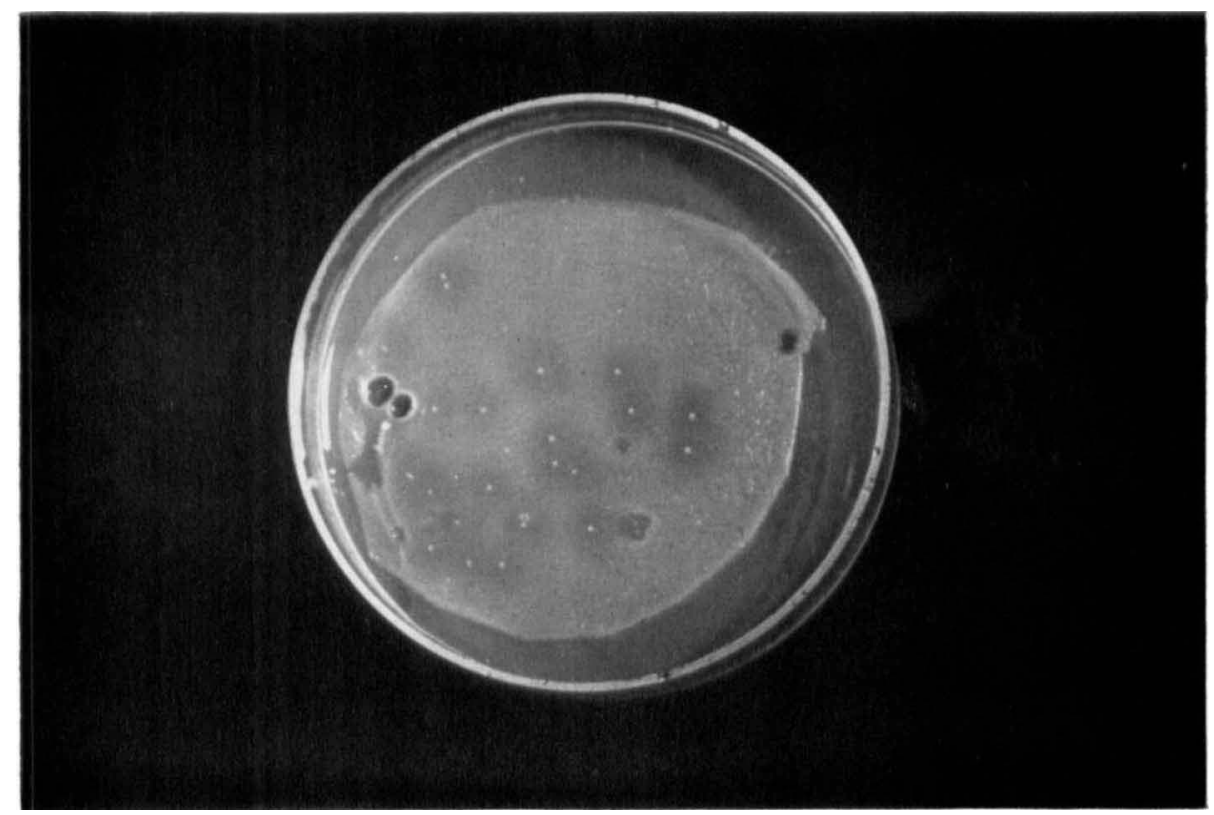

Fig. 1

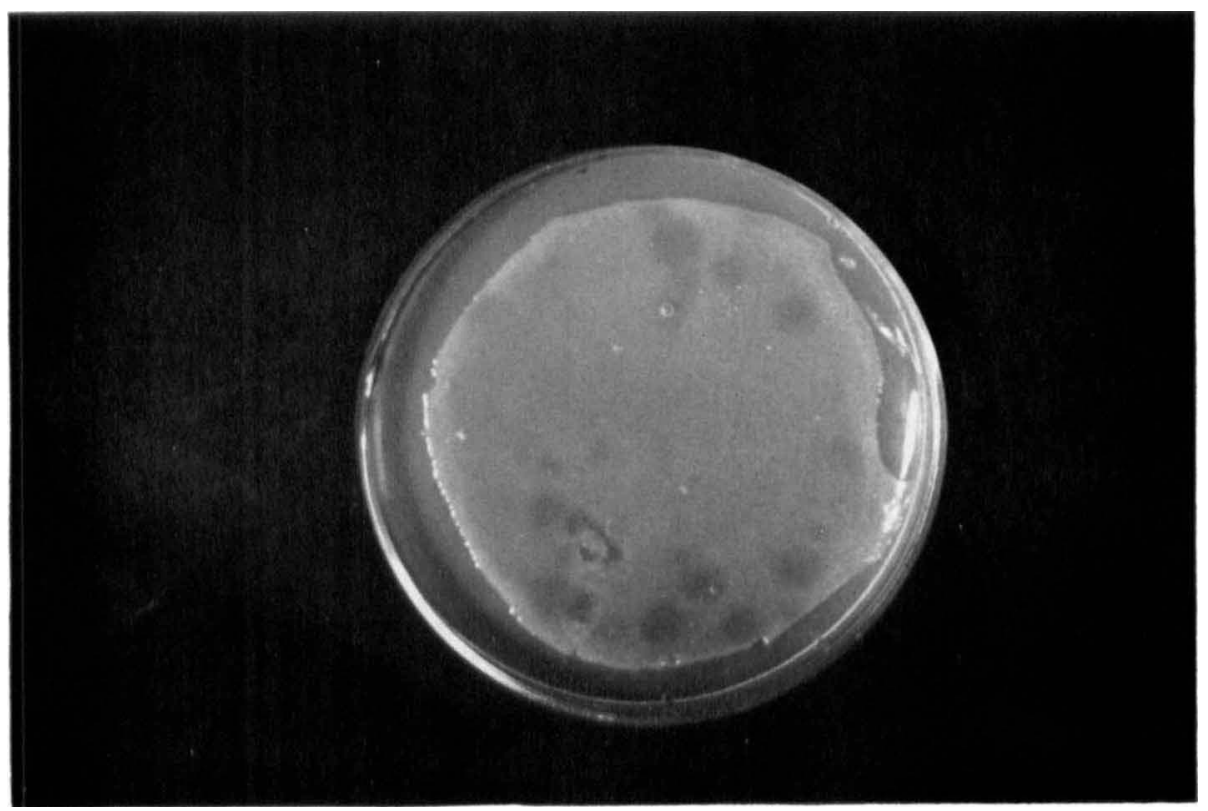

Fig. 2

R. Ben-Gurion \& I. Hertman-Pesticin. Plate 1 
Kellenberger, G. \& Kellenberger, E. (1956). Étude des souches colicinogènes au microscope électronique. Schweiz. Z. allg. Path. 19, 582.

LUdFord, C. G. \& Lederer, M. (1953). The antibiotics of E. coli. Aust. J. exp. Biol. med. Sci. 31, 553.

\section{EXPLANATION OF PLATE}

Fig. 1. Inhibition zones of Pasteurella pseudotuberculosis above colonies of $\boldsymbol{P}$. pestis.

Fig. 2. Inhibition zones of Pasteurella pseudotuberculosis produced by irradiation of microcolonies of $P$. pestis.

(Received 14 March 1958) 